\title{
THE EFFECTIVENESS OF DISCOVERY LEARNING TO IMPROVE CRITICAL THINKING SKILLS COLLEGE STUDENT ON MASTERY OF ARRHENIUS ACID BASE
}

\author{
Ratu Betta Rudibyani \\ Ratu.betta.r@gamil.com \\ Faculty of Teacher Training and Education, Lampung University, \\ Road. Prof. Dr. Soemantri Brojonegoro No.1
}

\begin{abstract}
The Effectiveness of Discovery learning to Improve Critical Thinking Skills college student on Mastery of Arrhenius Acid-Base. This research was aimed to describe the effectiveness of discovery learning to improving critical thinking skills on mastery of Arrhenius acid-base. The renewal of this research is the integration of discovery learning models, The 2013 curriculum structure, Arrhenius acid-base material with aspects of critical thinking skills according by Ennis. This research used quasiexperiment with pretest-postest non-equivalent control group design. The population in this research is all college students of Master Program of Chemistry Education, Faculty of Teacher Training and Education, Lampung University Academic year 2017/2018. The sample is taken by cluster random sampling technique and obtained sample that is class A as experiment class were 31 students and Class B as control class was 30 students. The results showed that the effectiveness of discovery learning by n-Gain value had high criteria and effect size had large criteria. Based on the result of this research shown that discovery learning effective and have a high effect size in improving critical thinking skills on mastery of Arrhenius acid base.
\end{abstract}

Keywords: discovery learning, critical thinking skills

\section{PRELIMINARY}

The current study of science is still far from expectations (Pongsophon \& Herman, 2017). This is evidenced based on surveys conducted by TIMSS and PISA on the ability of students' reasoning and the ability to apply the concept in daily life in science subjects. The results of a survey conducted by TIMSS in 2015, states that Indonesia is ranked 44 out of 47 countries and the learning process is included in the category of low performers (TIMSS, 2015). PISA survey results in 2015 mention that Indonesia is ranked 62 out of 69 countries (PISA, 2015). Based on a survey conducted by both institutions, it gives meaning that on the mastery of the concept of Indonesian students in the field of IPA low effect on low student learning outcomes.

One branch of science that is chemistry. Chemical learning should take into account the characteristics of chemistry as attitude, process, and product (Permendikbud, 2014).Chemistry is one of the most difficult lessons for most middle school students and 
students. The difficulty of studying chemistry is related to the characteristics of chemistry and the difficulty in understanding the concept of chemistry. Most chemistry is abstract. Chemistry subject matter is very complex.

Based on the results of discussions and observations with the team of chemistry lecturers proves that the learning of chemistry is still not paying attention and training characteristics of chemistry as attitude, process, and product. The lecturing process, the lecturer has created a student discussion group, but the group is used to discuss training questions that contain the application of the material that the lecturer has given. It then raises the problem that is the lectures obtained by the students is not the result of the process of finding themselves but from the information given by the lecturer, the students get less chance to be actively involved, and the less able students to enrich and develop an idea or product and add or detailing the details of an object, idea or situation so that it becomes more interesting for the students themselves and the mastery of student concepts is still low. Efforts are made to overcome these problems is by improving the lecture that can be done by using discovery learning.

Discovery learning is a learning where students learn to find and find the concept independently(Künsting, et al., 2013;Khabibah, 2017). The discovery learning model enables students to play an active role in the learning process by answering and solving problems to find a long-lasting and memorable concept (Meador, 2005, Maarif, 2016). Thus the discovery learning model is expected to be used to train students to think critically.

Critical thinking skills are the process of challenging individuals to reflect reflective, systematic, logical, scientific, clear and rational, rational thinking to collect, interpret and evaluate information in making decisions(Facione, 2011; Lai, 2011; Marin \& Halpern, 2011).According to Ennis(1989), there are 12 indicators of critical thinking skills contained in five groups of thinking skills. The five groups of skills include: providing simple explanations (elementary clarification), building basic skills, interference, making a further clarification, and strategies and tactics).The trained students to be skilled in critical thinking is expected to improve student learning outcomes through discovery learning model(Haseli, 2013; Huang, et al., 2016).

One of the chemicals given to the Basic Chemistry Course is acid-base material. The basic acidic material to be conducted is Arrhenius acid base. In this study, students can be invited to observe the phenomenon of an acid-base solution and conduct experiments so that students are directly involved in scientific work that can train students' critical thinking skills(Lunenburg, 2011; Driver et al., 2015).

Implementation using discovery learning model is expected to be student-centered learning(Huang et al., 2016;Larsson, 2017). Students are more active in learning activities, discoveries independently, build experiences, mastery of the concept of the material being studied and improve elaboration thinking skills (McHaney, 2012). Discovery learning models are expected to explore students' critical thinking skills better(Kistner, et al, 2016; Chen, et al., 2016).Based on the above description, then conducted this research with the aim of describing the effectiveness of discovery learning to improve students' critical thinking skills on Arrhenius acid - base material. 


\section{RESEARCH METHODS}

\section{Research Method and Design}

The method used in this research is quasi-experimental with non-equivalent pretestposttest control group design (Fraenkel, 2012).Class A is an experimental class (using discovery learning model) and class B is a control class (using lecture learning models). Both classes get a pretest before receiving treatment later by giving a posttest.

\section{Population and Sample}

Population in this research is all student of Master Program of Chemistry Education, Faculty of Teacher Training and Education, Lampung University Academic year 2017/2018. Sampling using cluster random sampling technique and obtained sample that is class A as experiment class were 31 studentsand Class B as control class were 30 students.

\section{Learning Media and Research Instruments}

Learning instruments that are used in this research are the syllabus, Semester Course Plan (RPS), and 4 types of LKS. The instrument used is a test of critical thinking skills that are adapted to aspects of critical thinking skills according to Ennis (1989). Item questions are pretest and posttest consisting of 10 items of multiple choice questions and 5 description questions to measure students' critical thinking skills. Lecturer's observation sheet in managing to learn using discovery learning model.

\section{Data Analysis Technique}

Data analysis is done including instrument validity and reliability, effectiveness, and size of influence. Data analysis was calculated using SPSS software. 17.0 and Microsoft Office Excel.

Instrument validity and reliability were analyzed with Iceman version 4.3 for multiple choice questions and SPSS 17.0 for description. On multiple choice questions, the validity is determined from the total value of Rpbis while the reliability of the question is determined by the value of Alpha. The validity and reliability criteria according to Arikunto (2004) are shown in table 1.

TABLE 1. Criteria for Validity dan Reliability

\begin{tabular}{cc}
\hline $\begin{array}{c}\text { Alpha dan Rpbis } \\
\text { Value }\end{array}$ & Interpretation \\
\hline $0,81-1,00$ & Very High \\
$0,61-0,80$ & High \\
$0,41-0,60$ & Sufficient \\
$0,21-0,40$ & Low \\
$0,00-0,20$ & Very Low \\
\hline
\end{tabular}


On the matter of description, the validity of the description is determined from the value of rtable and $r$ count with the question creiteria said valid if rtable $<r$ count with $5 \%$ significant level. Reliability is determined using Cronbach's Alpha. Criteria reliability of essays if Alpha Cronbach $\geq \mathrm{r}$ table. The reliability criterion (r11) according to Guilford is shown in Table 2.

TABLE 2. Criteria for Reliability Degree

\begin{tabular}{lc}
\hline \multicolumn{2}{c}{$\begin{array}{c}\text { Level reliabilitas }\left(\mathbf{r}_{11}\right) \\
\text { Criteria }\end{array}$} \\
\hline $0,80<\mathrm{r} 11 \leq 1,00$ & Very High \\
$0,60<\mathrm{r} 11 \leq 0,80$ & High \\
$0,40<\mathrm{r} 11 \leq 0,60$ & Sufficient \\
$0,20<\mathrm{r} 11 \leq 0,40$ & Low \\
$0,00<\mathrm{r} 11 \leq 0,20$ & Not reliable \\
\hline
\end{tabular}

The effectiveness of discovery learning model determined from the ability of teacher in managing learning discovery learning. According Sunyono (2015) with the formula:

$$
\% J i=\left(\frac{\sum J i}{N}\right) \times 100 \%
$$

Description $\% J i=$ Percentage of an ideal score at the i-th meeting, $\Sigma J i=$ Total score of each observation aspect and $\mathrm{N}=$ Maximum score. Next, interpret the data by using the percentage price interpretation as in table 3 according to Ratumanan (in Sunyono, 2015).

TABLE 3. Criteria for teacher ability

\begin{tabular}{cc}
\hline \multicolumn{1}{c}{ Persentase } & Criteria \\
\hline $81,0 \%-100,0 \%$ & Very High \\
$61,0 \%-80,0 \%$ & High \\
$41,0 \%-60,0 \%$ & Sufficient \\
$21,0 \%-40,0 \%$ & Low \\
$0,0 \%-20,0 \%$ & Very Low \\
\hline
\end{tabular}

The effectiveness of the discovery learning model is also determined from the achievement in improving students' critical thinking skills as measured by then n-Gain values, namely the pretest and posttest values of the two classes. N-Gain formula:

$$
n-\text { Gain }=\frac{\% \text { posttest }-\% \text { pretest }}{100-\% \text { pretest }}
$$

With the n-Gain criteria according to Hake (1998) shown in Table 4. 
TABLE 4. Criteria of Skor n-Gain

\begin{tabular}{|c|c|}
\hline \multicolumn{2}{|c|}{ Skor $n$-Gain Criteria } \\
\hline$n$-Gain $>0,7$ & High \\
\hline $\begin{array}{l}0,3<n-\text { Gain } \leq \\
0,7\end{array}$ & Sufficient \\
\hline$n$-Gain $\leq 0,3$ & Low \\
\hline
\end{tabular}

The effect size of the discovery learning model on the improvement of critical thinking skills of Arrhenius acidic base students is determined based on t- test value. Before the t-test is done, first test normality and homogeneity test to $n-G a i n$ value.

The normality and homogeneity criteria of the sample are said to be normally distributed and have a homogeneous variance, if the sig value. Shapiro-Wilk>0.05. If the sample is normally distributed and homogeneous, then the parametric statistic test is the independent sample t-test on the $\mathrm{n}$-Gain of both classes with the accept criteria $\mathrm{H} 0$ if the sig value. (2-tailed) $<0.05$, which means the average $n$-Gain of students' critical thinking thinking skills using discovery learning is higher than the average $\mathrm{n}$-Gain critical thinking skills using conventional models and reject $\mathrm{H} 0$ otherwise. Then test the independent sample $\mathrm{t}$-test on the value of pretest and posttest of both classes.

Based on t-count value obtained from the independent sample t-test test of pretest and posttest value, the calculation is done to determine effect size. The calculation of effect size test according to Jahjouh (2014) used the following formula.

$$
\mu^{2}=\frac{t^{2}}{t^{2+d f}}
$$

After the effect size value is obtained then it is interpreted by the effect size criterion according to Dincer (2015) as shown in Table 5.

TABLE 5. Criteria of Effect Size

\begin{tabular}{lc}
\hline $\begin{array}{c}\text { Effect size } \\
(\boldsymbol{\mu})\end{array}$ & Criteria \\
\hline$\mu \leq 0,15$ & Very small \\
$0,15<\mu \leq$ & Small \\
0,40 & \\
$0,40<\mu \leq$ & Sufficient \\
0,75 & \\
$0,75<\mu \leq$ & Big \\
1,10 & Very Big \\
$\mu>1,10$ &
\end{tabular}




\section{RESULTS AND DISCUSSION}

\section{Validty and Realiability}

Based on data validation and reliability of multiple choice questions, it shows that 10 multiple choice questions have RPbis and Alpha values above 0.41 so that 10 questions are declared valid and reliable with good enough category.

The result of validity and reliability test of multiple choice questions using Iteman 4.3 software is presented in Table 6 .

TABLE 6. Data on the validity and reliability of multiple choice items

\begin{tabular}{lccccc}
\hline $\begin{array}{c}\text { Item } \\
\text { Total }\end{array}$ & $\begin{array}{c}\text { Problem } \\
\text { Rpbis }\end{array}$ & $\begin{array}{c}\text { Criteria } \\
\text { Kevalidan }\end{array}$ & Alpha & $\begin{array}{c}\text { Reliable } \\
\text { Criteria }\end{array}$ & Description \\
\hline 1 & 0.448 & Good & 0.554 & Sufficient & Reliable and Valid \\
2 & 0.426 & Good & 0.565 & Sufficient & Reliable and Valid \\
3 & 0.420 & Good & 0.562 & Sufficient & Reliable and Valid \\
4 & 0.501 & Good & 0.555 & Sufficient & Reliable and Valid \\
5 & 0.410 & Good & 0.588 & Sufficient & Reliable and Valid \\
6 & 0.447 & Good & 0.555 & Sufficient & Reliable and Valid \\
7 & 0.510 & Good & 0.543 & Sufficient & Reliable and Valid \\
8 & 0.448 & Good & 0.554 & Sufficient & Reliable and Valid \\
9 & 0.438 & Good & 0.557 & Sufficient & Reliable and Valid \\
10 & 0.410 & Good & 0.574 & Sufficient & Reliable and Valid \\
\hline
\end{tabular}

The calculation results using SPSS version 17.0 software obtained Corrected ItemTotal Correlation value which shows the validity value of item description is shown in Table 7.

TABLE 7. Result of reliability test item description

\begin{tabular}{lcccc}
\hline $\begin{array}{c}\text { Quetion } \\
\text { Number }\end{array}$ & $\boldsymbol{r}_{\text {hitung }}$ & Dk & $\mathbf{r}_{\text {tabel }}$ & Criteria \\
\hline 1 & 0,793 & 19 & 0,444 & Valid \\
\hline 2 & 0,696 & 19 & 0,444 & Valid \\
\hline 3 & 0,785 & 19 & 0,444 & Valid \\
\hline 4 & 0,696 & 19 & 0,444 & Valid \\
\hline 5 & 0,660 & 19 & 0,444 & Valid \\
\hline
\end{tabular}

Based on Table 7,it shows that the five items of the description have a value of $r$ count $>$ rtable, so that the five items of the description are declared valid.

The results of the reliability calculation of five questions described from the value of Cronbach's Alpha is equal to 0.764 which means the five questions have a highreliability description. 
Good instruments must meet two important requirements that are valid and reliable (Arikunto, 2006). Based on the results of the validity and reliability test, the test instrument with ten multiple choice questions and five descriptive descriptions is used to measure students' critical thinking skills.

\section{The Effectiveness of Discovery Learning}

Observation on the ability of teachers to manage the learning done by two observers during the learning took place by using the lecturer's observation capability in managing the lectures.

The calculation result shows the average skill of lecturer in managing lecture category "very high" with the average percentage of achievement of $78.43 \%$. This means that the ability of lecturers in managing discovery learning lectures has been running well that can be seen from aspects of preliminary observation, syntax, closing, and assessment of lecturers.

The results of observations from both observers on the ability of lecturers in teach model discovery learning on Arrhenius acid-base material shown in Table 8.

TABLE 8. Lecturer's Ability in Managing Lectures

\begin{tabular}{|c|c|c|c|c|c|}
\hline \multirow{3}{*}{ Meeting } & \multicolumn{5}{|c|}{ The Average percentage of proficiency of lecturer (\%) } \\
\hline & \multicolumn{4}{|c|}{ aspects of observation } & \multirow{2}{*}{$\begin{array}{c}\text { The average } \\
\text { of each } \\
\text { meeting }\end{array}$} \\
\hline & Introduction & Syntax & Closing & assessment of lecturers & \\
\hline 1 & 59.00 & 71.67 & 63.00 & 73.00 & 66.67 \\
\hline 2 & 75.00 & 79.83 & 75.00 & 83.00 & 78.21 \\
\hline 3 & 78.00 & 82.83 & 81.00 & 85.00 & 81.71 \\
\hline 4 & 88.00 & 84.50 & 88.00 & 88.00 & 87.13 \\
\hline Average & 75.00 & 79.71 & 76.75 & 82,25 & 78.43 \\
\hline Criteria & Very High & $\begin{array}{l}\text { Very } \\
\text { High }\end{array}$ & $\begin{array}{l}\text { Very } \\
\text { High }\end{array}$ & Very High & Very High \\
\hline
\end{tabular}

The observation and assessment of the lecturers' ability to lecture shows that the average teacher's ability to manage the lectures at each meeting is an improvement. It is also seen from the number of students who are active in the lecture process to find the concept of a material independently, looking for a concept in detail and member-sentry in front of his friends on Arrhenius acid- base material, and add opinions of his friends have been very good, so that students start accustomed to the steps of discovery learning lecture model.

The ability of lecturers in managing good lectures will determine the success of an effective schooling process so that the desired lecture objectives can be achieved. The ability of lecturers in managing the lectures leads to the improvement of students' critical thinking skills. It can be seen from the ability of lecturers on syntax discovery learning that can be applied critical thinking skills that is in the second stage to sixth. 
The greatest percentage is in the ability of lecturers to carry out the collection, processing, and verification of the fourth meeting data. This is because at the meeting the lecturers have been accustomed and able to guide students in doing the lab so that students can collect data. Kemendikbud (2013) explains also in the data collection stage students will learn actively to find something related to the problem at hand, thus the students will connect with knowledge already possessed and at the stage of processing the data the students will get new knowledge of alternative answers that will later be proven at the stage of proof.

In the syntax of data processing, lecturers can provoke students thinking with questions to build concepts in solving problems and using the ideas and skills they have learned to discover new concepts. So through the active involvement of students themselves and involves an interaction between students and lecturers who are expected to hone the skills of critical thinking (Aun \& Kaewurai, 2017; Cargas, Williams, \& Rosenberg, 2017;Thomas, 2017). On the syntax of verification hypothesis /verification on learning discovery learning is supported by data collection activities through books /webblog or discuss with friends/lecturers (Wenning et al., 2011;Dalgarno, et al., 2014).

The effectiveness of learning discovery learning model is measured from the achievement in improving students' critical thinking skill which can be seen based on statistical calculation. The mean of the pretest value and posttest value is shown in Figure 1 , while the mean difference of $\mathrm{n}$-Gain is shown in Figure 2.

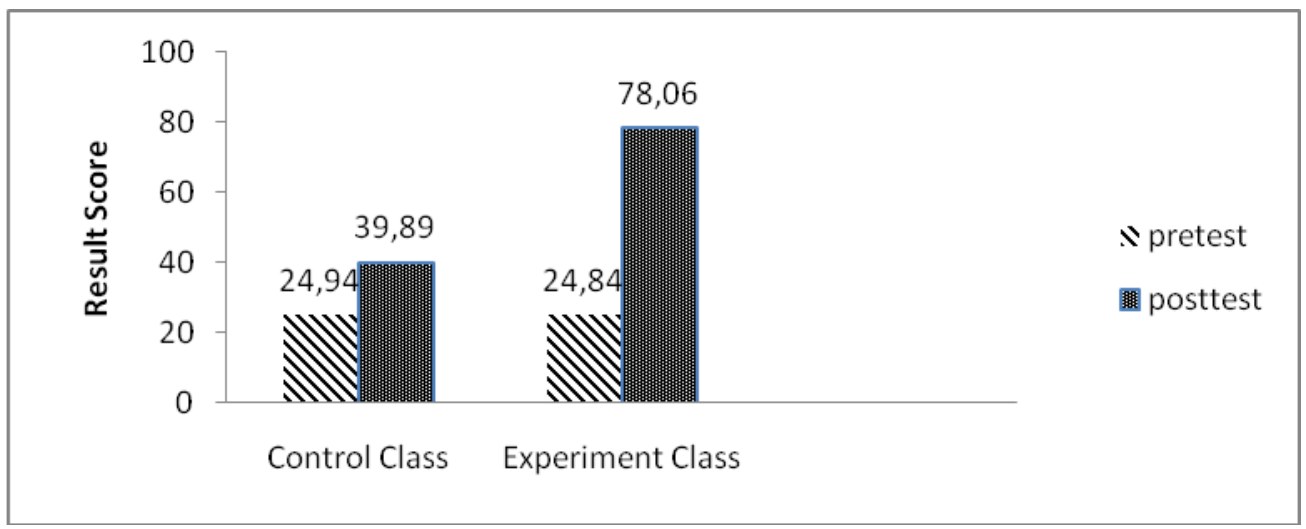

FIGURE 1. Average pretest posttest score

In Figure 1 it can be seen that the average of pretest values in control and experiment classes is in the range of value 24 so that it is in accordance with the researcher's assumption that both samples have the same initial knowledge. In addition, there is an increase in students' critical thinking skills after learning discovery learning in the experimental class and conventional learning in the control class. The mean values of pretest and posttest of students' critical thinking skills in the control class and experimental class have increased, but the increase in the pretest and posttest values in the experimental class is greater than the control class. This shows the average increase in pretest and postes values in the experimental class is greater than the control class. Thus, the skills of critical 
thinking in students after applied lectures with discovery learning are better than before applied lectures.

The improvement of students 'critical thinking skills is shown through then n-Gain value used to see a careful comparison between the difference between pretest and posttest values with the difference of maximum value and pretest value so that it can be known the effectiveness of the learning discovery learning model in improving students' critical thinking skills on acidic material the Arrhenius base presented in Figure 2.

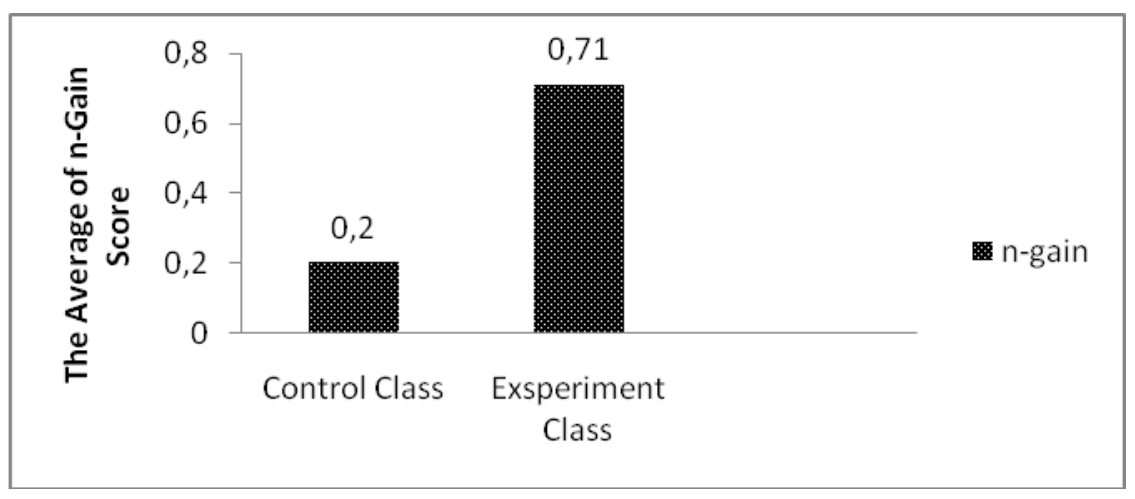

FIGURE 2. The average of n-gain score

Based on Figure 2 shows the average n-Gain score of the critical thinking skills of the experimental class students of 0.71 falling into the "high" criterion and n-Gain critical thinking skills of control class students by 0.20 falling within the criteria "low". This suggests that the average $n$-Gain of students 'critical thinking skills in the experimental class applied to the discovery learning model differs from the average n-Gain of students' critical thinking skills in the class applied to the conventional lecture model on Arrhenius acid-base material. This means that students 'critical thinking skills in the experimental class are better than the students' critical thinking skills in the control class.

\section{Hypothesis Testing}

The results of normality and homogeneity test of students' critical thinking in the experimental class and control class can be seen in the following table.

TABLE 9. Normality test results

\begin{tabular}{lccc}
\hline \multirow{2}{*}{ Class } & N & \multicolumn{2}{c}{$\boldsymbol{\text { Sig.Gain }}$} \\
\cline { 3 - 4 } & & $\begin{array}{c}\text { Test } \\
\text { Value }\end{array}$ & Criteria \\
\hline $\begin{array}{l}\text { Experime } \\
\text { nt }\end{array}$ & 31 & 0,110 & sig. $>0,05$ \\
\hline Control & 30 & 0,158 & sig. $>0,05$ \\
\hline
\end{tabular}


Based on Table 9 it can be seen that the normality test results against $n$-Gain values in control and experimental class have sig value. of Shapiro-Wilk in the experimental class and control class $>0.05$ so that the test decision receives $\mathrm{H} 0$ and reject $\mathrm{H} 1$ which means the research data obtained comes from the normally distributed population.

TABLE 10. Homogeneity Test Results

\begin{tabular}{|c|c|c|c|}
\hline \multicolumn{4}{|c|}{ n-Gain } \\
\hline Class & $\mathbf{N}$ & $\begin{array}{l}\text { Nilai } \\
\text { sig. }\end{array}$ & $\begin{array}{l}\text { Kriteria } \\
\text { uji }\end{array}$ \\
\hline $\begin{array}{l}\text { Experime } \\
\text { tt }\end{array}$ & $\begin{array}{l}3 \\
1\end{array}$ & 0,77 & sig. \\
\hline
\end{tabular}

Based on table 10 it is known that homogeneity test results on n-Gain values in control and experimental class have sig value. $>0.05$, so the test decision receives $\mathrm{H} 0$ and reject $\mathrm{H} 1$ which means both samples have homogeneous variance values.

\section{Two-n-Gain Difference Difference Test}

The results of the two-dimensional difference test of the $n$-Gain critical thinking of the students in the experimental class and the control class can be seen in table 11.

TABLE 11. Two-Dual Difference Test

\begin{tabular}{lcccc}
\hline Class & n & $\begin{array}{c}\text { Avera } \\
\text { ge }\end{array}$ & df & $\begin{array}{c}\text { sig. } \\
(2- \\
\text { tailed })\end{array}$ \\
\hline $\begin{array}{l}\text { Experime } \\
\text { nt }\end{array}$ & 31 & 0.71 & 59 & 0.00 \\
\hline
\end{tabular}

A two-averaging difference test was performed using an independent sample t-test in the SPSS 17.0 program with a significant level of 5\%. Criteria of test receipt $\mathrm{H} 1$ if the value of sig. (2-tailed) from the t-test for equality of means $<0.05$ and accept $\mathrm{H} 0$ otherwise. The result of the difference test of two average n-Gain students' critical thinking skills in the experimental class and control class shows that the sig value. (2-tailed) $<0.05$ so that the test decision receives $\mathrm{HO}$ and reject $\mathrm{H} 1$ meaning that there is a significant difference in the $\mathrm{n}$-Gain value for both classes ie the average value of $\mathrm{n}$-Gain critical thinking skills of the students in the experimental class applied by the model discovery learning is higher than control class using conventional methods on Arrhenius acid-base material.

Based on the test of difference of two mean and ability of lecturers in managing lectures show that lectures use discovery learning model which has done better in improving students' critical thinking skill. In accordance with Bruner's Discovery Learning theory which assumes that learning by discovery is in accordance with the active search for knowledge by humans and by itself gives the best result (Bruner, 1999). Discovery learning is based on the theory of constructivism, students must build their own knowledge in his 
mind. Knowledge gained can last longer and can improve students' reasoning, ability to think, and mastery of student concepts(Novak, 2002).

\section{Effect Size}

After doing a test of difference of two mean to n-Gain value, then to know how big influence effectiveness of learning discovery learning model calculation of effect size before must be known before t-value from the result of difference test of two mean to pretest value and posttest at experimental class and control class. The t-count value obtained from the difference test of two pretest-posttest with independent sample t-test is tvalue in experiment class of 33.499 and control class of 8,658 then used to calculate effect size on elaboration thinking skill and mastery of student concept in experiment class and the control classes shown in Table 13.

TABLE 12.Value of effect size in control and experiment class

\begin{tabular}{lcccccc}
\hline \multicolumn{1}{c}{ Class } & N & $\begin{array}{c}\text { D } \\
\text { f }\end{array}$ & t count & $\begin{array}{c}\text { sig.(2- } \\
\text { tailed) }\end{array}$ & $\begin{array}{c}\text { Nilai Effect } \\
\text { Size }\end{array}$ & $\begin{array}{c}\text { Kategor } \\
\text { i }\end{array}$ \\
\hline Experiment & 3 & 6 & 33.49 & 0,000 & 0.98 & Big \\
& 1 & 0 & 9 & & & \\
\hline Control & 3 & 5 & 8.658 & 0,000 & 0.75 & Medium \\
& 0 & 8 & & & & \\
\hline
\end{tabular}

Based on Table 12 above shows that the value of Sig. (2-tailed) in the two classes is smaller than 0.05 so receive $\mathrm{H} 1$, ie there is a significant difference in the average of pretest and posttest values for both classes. The value of effect size in the experimental class is 0.98, according to the criteria according to Dincer (2015) the value lies in the range of 0.75 $<\mu \leq 1.10$ with the category of "big effect" while in the control class has an effect size value of 0.75 , criterion according to Dincer (2015) the value lies in the range of $0.15<\mu \leq 0.75$ in the "moderate" category.

The results show that the effect of learning discovery learning model in the experimental class is greater than the control class on Arrhenius acid-base material. The improvement of thinking skill of elaboration and mastery of student concept in experiment class $98 \%$ influenced by discovery learning model while in control class $75 \%$ influenced by the conventional model.

Based on effectiveness test and effect size test shows that learning using discovery learning model has been done effectively and has a big influence in improving the thinking skill of elaboration and mastery of student concept. This is supported by research (Kistner et al., 2016) which states that the model of discovery learning can improve students' creative thinking skills and research Raab, et al., (2011)also shows that there is a correlation between the ability of creative thinking with student achievement. In addition, research conducted by Rogers(2010) states that the learning discovery learning model can be applied to the acid-base material to improve Flexible skills. Then (Martaida, et al.,(2017) concluded that learning discovery learning is said to be practical and effective in improving self-efficacy and mastering student concepts and having a large measure of influence. 
Bruner's study theory of discovery is closely related to creative thinking skills, that is, if students learn by actively participating in discovering concepts and principles and experimenting, can improve cognitive skills so that students are able to develop, enhance and enrich an idea, detailing and expanding an idea of the findings(Novak, 2002; Novank, 2011; Mogashoa, 2014). The ability to discover or be able to develop, add and enrich an idea, detailing, expanding an idea is one aspect of creative thinking skills. According to Dalgarno, et al., (2014) states that the ability to think elaboration and mastery of this concept can be used as a means so that students can express the findings and mastery of the concept in detail and detail. Therefore, when the students are trained in thinking elaboration and mastery of the concept then the student has also mastered the concept of material that has been found alone

\section{CONCLUSION}

The discovery learning model is effective in improving students' critical thinking skills on Arrhenius acid-base material. This is demonstrated by the students 'relevant activities in teaching and lecturers' ability to manage "very high" category advocates, as well as significant differences between n-Gain values in the control and experimental classes, where the control class has a more n-Gain big.

The discovery learning model has a "great" effect size in improving students' critical thinking skills on acid-base Arrhenius materials.

\section{REFERENCES}

Arikunto. 2006.The Basics of Education Evaluation.Jakarta: Bumi Aksara

Aun, S., \& Kaewurai, W. 2017. Kasetsart Journal of Social Sciences Instructional model development to enhance critical thinking and critical thinking teaching ability of trainee students at regional teaching training center in Takeo province, Cambodia. Kasetsart Journal of Social Sciences, 38(1), 88-95. http://doi.org/10.1016/j.kjss.2016.05.002

Bruner, J. (1999). The Process of Education, 1-128.

Cargas, S., Williams, S., \& Rosenberg, M. 2017. An approach to teaching critical thinking across disciplines using performance tasks with a common rubric. Thinking Skills and Creativity, 26, 24-37. http://doi.org/10.1016/j.tsc.2017.05.005

Chen, P., Tolmie, A. K., \& Wang, H. 2016. Growing the critical thinking of schoolchildren in Taiwan using the Analects of Confucius. International Journal of Educational Research, 84(2016), 43-54. http://doi.org/10.1016/j.ijer.2017.02.002

Dalgarno, B., Kennedy, G., \& Bennett, S. 2014. The impact of students ' exploration strategies on discovery learning using computer-based simulations, 37-41. http://doi.org/10.1080/09523987.2014.977009

Driver, R., Asoko, H., Leach, J., Mortimer, E., Scott, P., \& Hilary, D. 2015. in 
Scientific Knowledge the Classroom. American Education Research Association, 23(7), 5-12.

Ennis, R. 1998. Critical thinking. Teaching Philosophy, 14(1), 5-24. http://doi.org/10.1016/B978-0-12-375038-9.00057-1

Facione, P. a. 2011. Critical Thinking: What It Is and Why It Counts. Insight Assessment, (ISBN 13: 978-1-891557-07-1.), 1-28. http://doi.org/ISBN 13: 978-1891557-07-1.

Haseli, Z. 2013. The Effect of Teaching Critical thinking on Educational Achievement and Test Anxiety among Junior High School Students in Saveh, 2(2), 168-175.

Huang, T. C. K., Huang, C. H., \& Chuang, Y. T. 2016. Change discovery of learning performance in dynamic educational environments. Telematics and Informatics, 33(3), 773-792. http://doi.org/10.1016/j.tele.2015.10.005

Khabibah, E. N. 2017. The Effectiveness of Module Based on Discovery Learning to Increase Generic Science Skills. Journal of Education and Learning, 11(2), 146153. http://doi.org/10.11591/edulearn.v11i2.6076

Kistner, S., Vollmeyer, R., Burns, B. D., \& Kortenkamp, U. 2016. Model development in scientific discovery learning with a computer-based physics task. Computers in Human Behavior, 59, 446-455. http://doi.org/10.1016/j.chb.2016.02.041

Künsting, J., Kempf, J., \& Wirth, J. 2013. Enhancing scientific discovery learning through metacognitive support. Contemporary Educational Psychology, 38(4), 349-360. http://doi.org/10.1016/j.cedpsych.2013.07.001

Lai, E. R. 2011. Critical Thinking: A Literature Review Research Report, (June).

Larsson, K. 2017. Understanding and teaching critical thinking-A new approach. International Journal of Educational Research, 84, 32-42. http://doi.org/10.1016/j.ijer.2017.05.004

Lunenburg, F. C. 2011. Critical Thinking and Constructivism Techniques for Improving Student Achievement, 21(3), 1-9

Maarif, S. 2016. Improving junior high school students' mathematical analogical ability using discovery learning method. International Journal of Research in Education and Science (IJRES), 2(1), 114- 124.

Marin, L. M., \& Halpern, D. F. 2011. Pedagogy for developing critical thinking in adolescents: Explicit instruction produces greatest gains. Thinking Skills and Creativity, 6(1), 1-13. http://doi.org/10.1016/j.tsc.2010.08.002

Martaida, T., Bukit, N., \& Ginting, E. M. 2017. The Effect of Discovery Learning Model on Student' s Critical Thinking and Cognitive Ability in Junior High School, 7(6), 1-8. http://doi.org/10.9790/7388-0706010108

Meador, K. S. 2005. Thinking Creatively About Science: Suggestions 
for Primary Teachers. Science Education for Gifted Students., 1322. Retrieved from http://ovidsp.ovid.com/ovidweb.cgi?T=JS\&PAGE=reference \&D= psyc4\&NEWS=N\&AN=2005-13478-002

Mogashoa, T. 2014. Applicability of Constructivist Theory in Qualitative Educational Research. American International Journal of Contemporary Research, 4(7), 5159.

Novak, J. D. 2002. Meaningful Learning: The Essential Factor for Conceptual Change in Limited or Inappropriate Propositional Hierarchies Leading to Empowerment of Learners. Science Education, 86(4), 548-571. http://doi.org/10.1002/sce.10032

PISA.2015. Programme for international student assesment. http://www.oecd.org.

Permendikbud. 2014. Minister of Education and Culture Republic of Indonesia number 59 year 2004

Pongsophon, P., \& Herman, B. C. 2017. A theory of planned behaviour-based analysis of TIMSS 2011 to determine factors influencing inquiry teaching practices in high-performing countries. International Journal of Science Education, 39(10), 1304-1325. http://doi.org/10.1080/09500693.2017.1328620

Raab, M., Masters, R. S. W., \& Maxwell, J. 2011. International Journal of Sport and Discovery learning in sports : Implicit or explicit processes, 37-41.

Sunyono. 2015. Multiple Representation learning model. Yogyakarta: Media Academic

Rogers, P. 2010. British Journal of Educational “ Discovery ”, learning, critical thinking , and the nature of knowledge, (January 2015), 37-41. http://doi.org/10.1080/00071005.1990.9973831

Thomas, T. 2017. Developing First Year Students ' Critical Thinking Skills, 7(4), 2635. http://doi.org/10.5539/ass.v7n4p26

TIMSS.20. Student achievement of science. www. Timss.org

Wenning, C. J., Ed, D., Khan, M. A., Lecturer, S., Khan, A., \& Secondary, H. 2011. Levels of Inquiry Model of Science Teaching: Learning sequences to lesson plans, 6(2), 17-20. 